\title{
METABOLISM OF SPERMATOZOA AND COMPOSITION OF FLUID COLLECTED FROM THE RETE TESTIS OF LIVING BULLS
}

\author{
J. K. VOGLMAYR, L. H. LARSEN* AND I. G. WHITE \\ Department of Veterinary Physiology and *Department of Veterinary Surgery, \\ University of Sydney, Sydney, N.S.W. 2006, Australia
}

(Received 11th February 1969)

\begin{abstract}
Summary. A technique for collecting spermatozoa and fluid directly from the testis of the living bull is described. Rete testis fluid was secreted at a mean rate of $12.0 \mathrm{ml} / 100 \mathrm{~g}$ of testis/day and spermatozoa were present at a mean concentration of $92 \times 10^{6} \mathrm{cells} / \mathrm{ml}$. Chemical analyses have been made on rete testis fluid and its constituents compared with those of blood plasma from the same bulls. The fluid is iso-osmotic with blood plasma and contains less sodium, calcium, magnesium, inorganic phosphorus and protein but more potassium, chloride and glutamic acid. The concentration of urea and lactic acid was similar in rete testis fluid and blood plasma. Testosterone and androstenedione were found in the fluid of one mature bull at a concentration of 2.7 and $1.7 \mu \mathrm{g} / 100 \mathrm{ml}$ of fluid, respectively.

High concentrations of phosphate $(80 \mathrm{~mm})$ depress the respiration and glycolysis of ejaculated spermatozoa but stimulate that of testicular spermatozoa. In low phosphate diluent $(20 \mathrm{~mm})$, testicular spermatozoa converted a higher percentage of the utilized glucose to carbon dioxide than ejaculated cells and, under all conditions of incubation, accumulated more lactic acid in the media than could have arisen from the glucose utilized. There was no evidence of pentose-shunt activity in either testicular or ejaculated spermatozoa.
\end{abstract}

\section{INTRODUCTION}

The epididymis is an important part of the excurrent duct system in which spermatozoa undergo extensive morphological and physiological changes known as 'maturation' (see Bishop \& Walton, 1960; Bishop, 1961; Mann, 1964). In the bull, this requires an average of 11 days (Orgebin-Crist, 1961) and, in order to understand the process, fluid (Redenz, 1925; Salisbury \& Cragle, 1956; Crabo \& Gustafsson, 1964; Crabo, 1965; Gustafsson, 1966; Wales, Wallace \& White, 1966) and spermatozoa (Redenz, 1933; Henle \& Zittle, 1942; Lardy, Hansen \& Phillips, 1945) collected from the testis and epididymis at slaughter have been studied. Recently, such studies have been 
greatly facilitated by the development of a technique for collecting spermatozoa and fluid directly from the testis of living rams (Voglmayr, Waites \& Setchell, 1966; Voglmayr, Scott, Setchell \& Waites, 1967; Scott, Voglmayr \& Setchell, 1967; Setchell, Hinks, Voglmayr \& Scott, 1967; Murdoch \& White, 1968). This paper describes an extension of the technique to the bull and, to our knowledge, this study represents the first evaluation of testicular secretion from this animal while still alive.

\section{MATERIALS AND METHODS}

\section{Animals}

Two Holstein bulls ( $1 \frac{1}{2}$ years old and weighing 450 and $500 \mathrm{~kg}$ ) and one Ayrshire bull ( 3 years old, weighing $700 \mathrm{~kg}$ ) were fed on $15 \mathrm{~kg}$ lucern hay per day. The animals were supported by a heavy duty canvas sling in a covered yard.

\section{Collection of testicular secretion}

The surgical procedure was similar to that described previously for the ram (Voglmayr et al., 1967). General anaesthesia was induced by intravenous injection of $10 \%$ thiopentone sodium $(10 \mathrm{mg} / \mathrm{kg})$ and maintained with Fluothane (ICI) administered in a closed circuit system. Under aseptic precautions, the head of the epididymis was exposed through a 5-cm incision on the lateral surface of the scrotum and tunica vaginalis. The head of the epididymis was then carefully dissected from the tunica albuginea until the efferent ducts were located. Dissection was continued around the tubules until two fine ligatures could be passed behind these. Exerting tension on the tubules by means of one of the two ligatures, a cataract needle $(5 \times 2 \mathrm{~mm}$, Heiss, Germany) was inserted through the tubules into the rete testis (Pl. 1, Fig. A). The incision was extended with dilators (Pl. 1, Fig. B) so that a fine silicone rubber catheter (Voglmayr et al., 1967) with a stainless steel stillette in its lumen could be placed into the rete testis (Pl. 1, Fig. C). After securing the catheter above its cuff with the second ligature around all the efferent ducts, the stillette was withdrawn (Pl. 1, Fig. D). The catheter was brought to the exterior as described by Voglmayr et al. (1967). The testicular secretion was collected into a polyethylene receptacle attached to the anterior surface of the scrotum and was kept below $20^{\circ} \mathrm{C}$ by evaporative cooling.

\section{Collection of ejaculated spermatozoa}

Semen was collected either by an artificial vagina or by electro-ejaculation using the apparatus described by Martin \& Rees (1962).

\section{Preparation and incubation of sperm suspensions}

Testicular spermatozoa, collected over a period of up to $12 \mathrm{hr}$, were separated from rete testis fluid by centrifugation at $400 \mathrm{~g}$ for $6 \mathrm{~min}$. Ejaculated semen was diluted with one volume of diluent and centrifuged at $400 \mathrm{~g}$ for $8 \mathrm{~min}$. After aspirating the supernatant, the spermatozoa were resuspended in diluent and centrifuged again. The supernatant was removed and the spermatozoa 

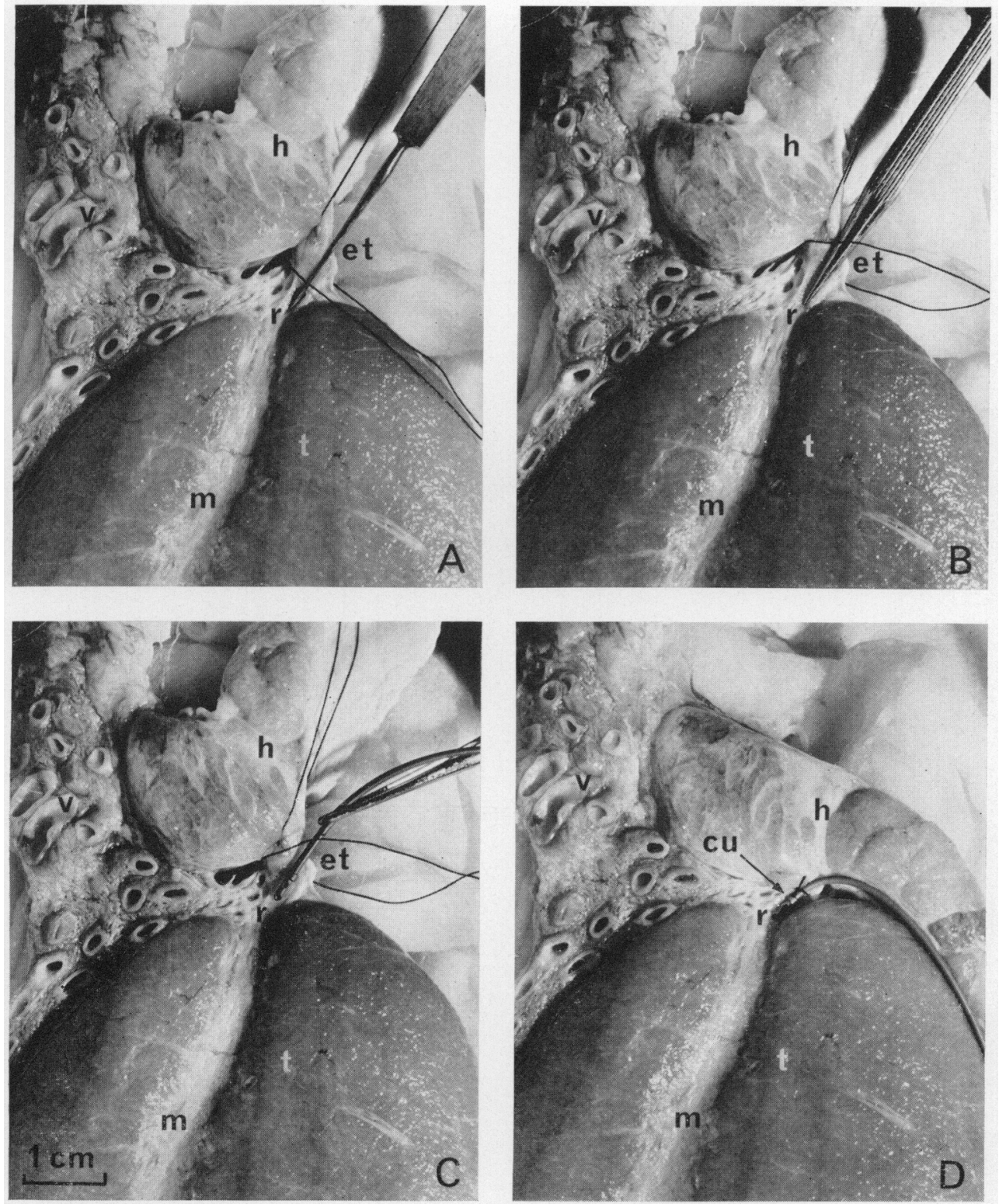

Sagittal section through the testis of a mature bull, demonstrating successive steps in the technique for cammulating the rete testis. Fig. A. Cataract needle inserted through the efferent tubules (ct) into rete testis (r) following dissection of the head of epididymis (h) from the tunica albuginea; $v$, vascular cone, t, testicular parcnchyma, m, mediastirnum. lïg. B. Incision dilated. Fig. C. Catheter inserted into dilated incision until its cuff is well inside efferent tubules. Fig. D. Catheter secured above cufl (cu) around all efferent tubules with second ligature and brought to exterior from under the head of cpididymis. 


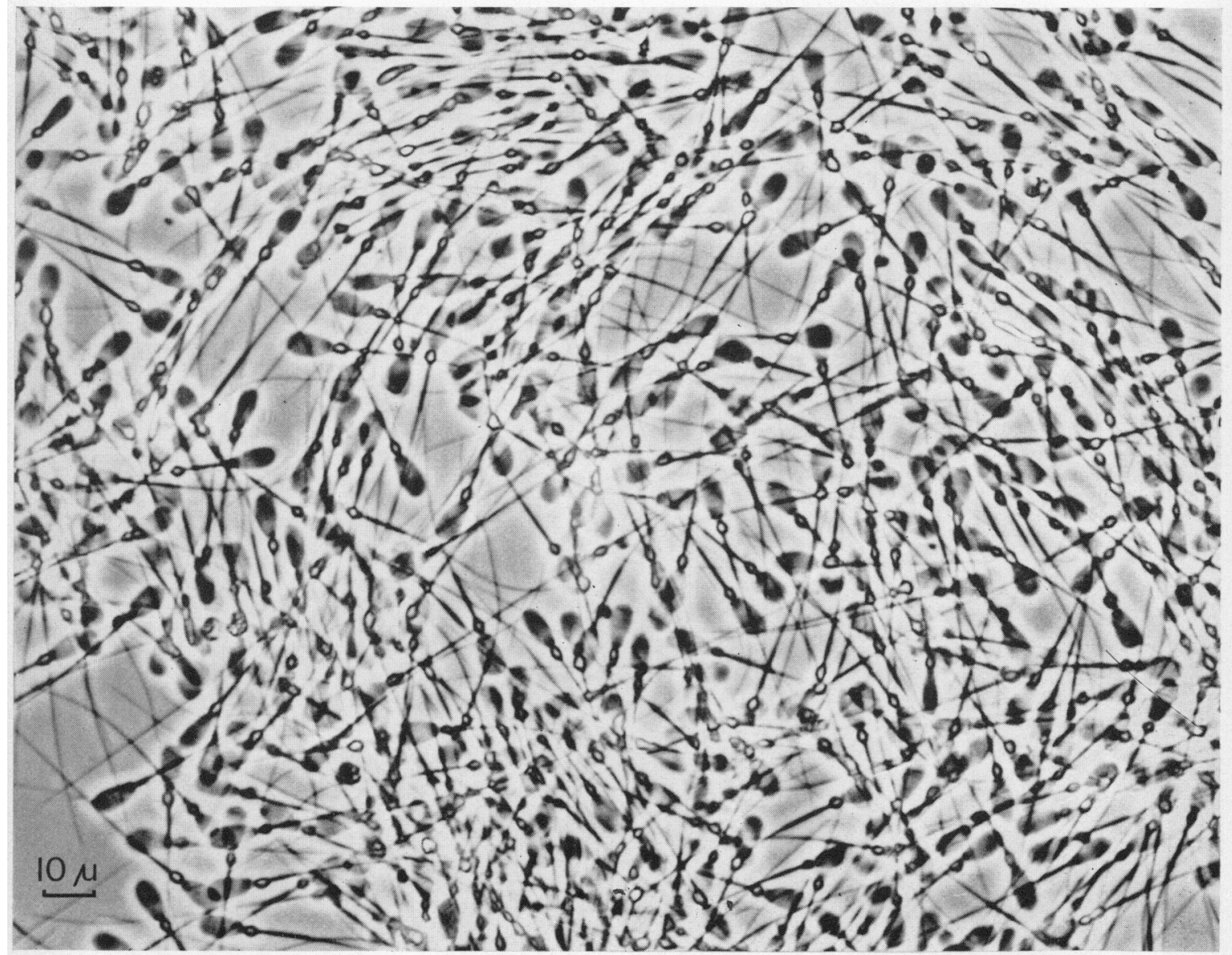

Photomicrograph of a sperm suspension collected from the rete testis of the living bull by the catheter. Note prominent kinoplasmic droplets. (Phase contrast.) 
were resuspended in appropriate incubation media to a final concentration of approximately $10^{8}$ cells $/ \mathrm{ml} /$ flask. The spermatozoa were incubated in Warburg flasks (3- to $4-\mathrm{ml}$ ) at $37^{\circ} \mathrm{C}$ and shaken at a rate of 120 strokes/min. Duplicate incubations were made on spermatozoa from each of at least two collections per animal. Before incubation, the washed sperm suspensions were checked for bacterial contamination by phase contrast microscopy and the percentage of dead spermatozoa assessed by staining with nigrosin-eosin (Hancock, 1952).

\section{Diluents and substrate}

Spermatozoa were incubated in either a high phosphate diluent $(80 \mathrm{~mm})$ containing $36 \mathrm{~mm}$-sodium chloride, 4 mm-potassium chloride and $2 \mathrm{~mm}$ magnesium chloride or a low phosphate diluent $(20 \mathrm{~mm})$ of the same ionic composition, where sodium chloride was added at the expense of phosphate ( $\mathrm{pH} 7 \cdot 1$ ). Radio-active D-glucose $\left[\mathrm{U}-{ }^{14} \mathrm{C}\right],\left[1-{ }^{14} \mathrm{C}\right]$ and $\left[6-{ }^{14} \mathrm{C}\right]$ (Radiochemical Centre, Amersham, Buckinghamshire) was checked for its purity by chromatographic procedures (see below) and added to the media to give a final concentration of $0.6 \mu \mathrm{Ci} / 700 \mu \mathrm{g} /$ flask.

\section{Analytical procedures}

Oxygen uptake was measured at 30-min intervals by the direct manometric technique of Umbreit, Burris \& Stauffer (1959). Radio-active carbon dioxide was collected in the centre well by the method described by Buhler (1962). After incubation, the sperm suspensions were deproteinized by adding $0.5 \mathrm{vol}$. of $5 \%(\mathrm{w} / \mathrm{v}) \mathrm{ZnSO}_{4} .7 \mathrm{H}_{2} \mathrm{O}$ and 0.5 vol. of $0.3 \mathrm{~N}-\mathrm{Ba}(\mathrm{OH})_{2}$. Glucose, lactic acid and amino acids in the neutral filtrates were assayed by chromatographic procedures (Freinkel, Cohen, Arky \& Foster, 1965) and by enzymatic methods (Huggett \& Nixon, 1957; Barker \& Britton, 1957; Sowerby \& Ottaway, 1966). Radio-activity was measured by an automatic liquid scintillation spectrometer (Packard Instrument Co., La Grange, Illinois). Sodium and potassium were measured by flame photometry and calcium and magnesium were estimated by atomic-absorption spectroscopy (Willis, 1965). Chloride was determined by the procedure of Zall, Fisher \& Garner (1956) adapted for the auto analyser and urea by the method of Wilson (1966), using urease and phenol. Inorganic phosphorus was estimated by the procedure of Fiske \& Subbarow (1925) after deproteinization with trichloroacetic acid. Protein was measured with Folin phenol by the method of Lowry, Rosebrough, Farr \& Randall (1951). Testosterone and androstenedione were identified chromatographically in a Bush A type system according to their mobility and u.v. absorption (Bush, 1952).

\section{Statistical methods}

The statistical significance of the results has been determined by analysis of variance.

\section{RESULTS}

Secretion of spermatozoa and fluid from the testis

Abundant quantities of testicular fluid were obtained for up to 10 days and 
there was little contamination with extraneous cells (Plate 2). The volume of the fluid secreted by the testis of a mature bull was about $40 \mathrm{ml}$ per day $(12.0$ $\mathrm{ml} / 100 \mathrm{~g}$ of testis/day; S.E. $\pm 1 \cdot 1$ ) during the first 4 to 5 days and then declined to about $60 \%$ of this volume by the 10 th day.

The concentration of spermatozoa remained fairly constant throughout the collection period and the output of spermatozoa followed the same pattern as the volume of the rete testis fluid. Spermatozoa, all with prominent kinoplasmic droplets, were present at a concentration of $91.6 \times 10^{6} \mathrm{cells} / \mathrm{ml}$ (S.E. \pm 7.05 ; three bulls) so that the daily production was $1.1 \times 10^{9}$ spermatozoa/100 $\mathrm{g}$ of testis (S.E. $\pm 0 \cdot 1$ ).

The initial $\mathrm{pH}$ of the fluid was 7.2 but rose to 8.5 after several hours. Almost all the spermatozoa were immotile but a few showed slow oscillating movements without progression. Storage for 3 days at $3^{\circ} \mathrm{G}$ did not produce any increase in motility.

TABLE 1

CONSTITUENTS AND PROPERTIES OF RETE TESTIS FLUID AND BLOOD PLASMA COLLECTED FROM THE SAME BULLS

\begin{tabular}{|c|c|c|}
\hline Constituent & Rete testis fluid & Blood plasma \\
\hline $\begin{array}{l}\text { Sodium } \\
\text { Potassium } \\
\text { Calcium } \\
\text { Magnesium } \\
\text { Chloride } \\
\text { Inorganic phosphorus } \\
\text { Urea } \\
\text { Protein } \\
\text { Glucose } \\
\text { Lactic acid } \\
\text { Glutamic acid } \\
\text { Osmolality (m-osmole/kg) }\end{array}$ & $\begin{array}{r}306.3 \pm 3.00 \\
35.3 \pm 1.39 \\
1.9 \pm 0.33 \\
1.0 \pm 0.03 \\
433.6 \pm 3.18 \\
0.08 \pm 0.02 \\
35.1 \pm 1.24 \\
210.6 \pm 22.13 \\
\text { trace } \\
6.6 \pm 1.66 \\
19.5 \pm 1.59 \\
280.8 \pm 2.86\end{array}$ & $\begin{aligned} & 318 \cdot 1 \pm 1.44 \\
& 16 \cdot 7 \pm 0.44 \\
& 7 \cdot 9 \pm 0.24 \\
& 2 \cdot 1 \pm 0.05 \\
& 330 \cdot 7 \pm 5 \cdot 13 \\
& 7 \cdot 1 \pm 0.99 \\
& 36 \cdot 1 \pm 1.99 \\
& 8997 \cdot 3 \pm 237 \cdot 0 \\
& 81 \cdot 3 \pm 1.68 \\
& 13 \cdot 1 \pm 3 \cdot 6 \\
& 7.2 \pm 0.62 \\
& 281.5 \pm 1.79\end{aligned}$ \\
\hline
\end{tabular}

Values $(\mathrm{mg} / 100 \mathrm{ml})$ are the mean \pm S.E. from at least three collections from each of three animals.

\section{Composition of rete testis fluid and comparison with blood plasma}

Table 1 shows the concentration of constituents in the rete testis fluid and blood plasma of three bulls. Rete testis fluid was iso-osmotic with the blood plasma and contained less sodium but about twice as much potassium. Calcium and magnesium were present in much lower concentrations than in plasma but the fluid contained about $31 \%$ more chloride and about three times more glutamic acid than blood plasma. There was very little inorganic phosphorus in the rete testis fluid, about $1.1 \%$ of plasma values and only traces of glucose were detectable. The concentration of urea was similar in rete testis fluid and blood plasma. Lactic acid was present in either higher or lower concentrations than in plasma where it varied considerably (range 3 to $44 \mathrm{mg} / 100 \mathrm{ml}$ ) depending on the excitation of the animal during blood collection. Rete testis fluid contained very little protein, about $2.3 \%$ of blood plasma content. The fluid of one animal (a 3-year-old Ayrshire bull) contained 2.7 $\mu \mathrm{g}$ testosterone and 
$1.7 \mu \mathrm{g}$ androstenedione $/ 100 \mathrm{ml}$, whereas in the other two bulls these steroids were not detectable.

\section{Comparison of the metabolism of testicular and ejaculated spermatozoa}

Oxygen uptake. The oxygen uptake of testicular spermatozoa was always linear over $3 \mathrm{hr}$ incubation and was higher in high phosphate diluent than in low phosphate diluent (Text-fig. 1). In low phosphate diluent, the oxygen

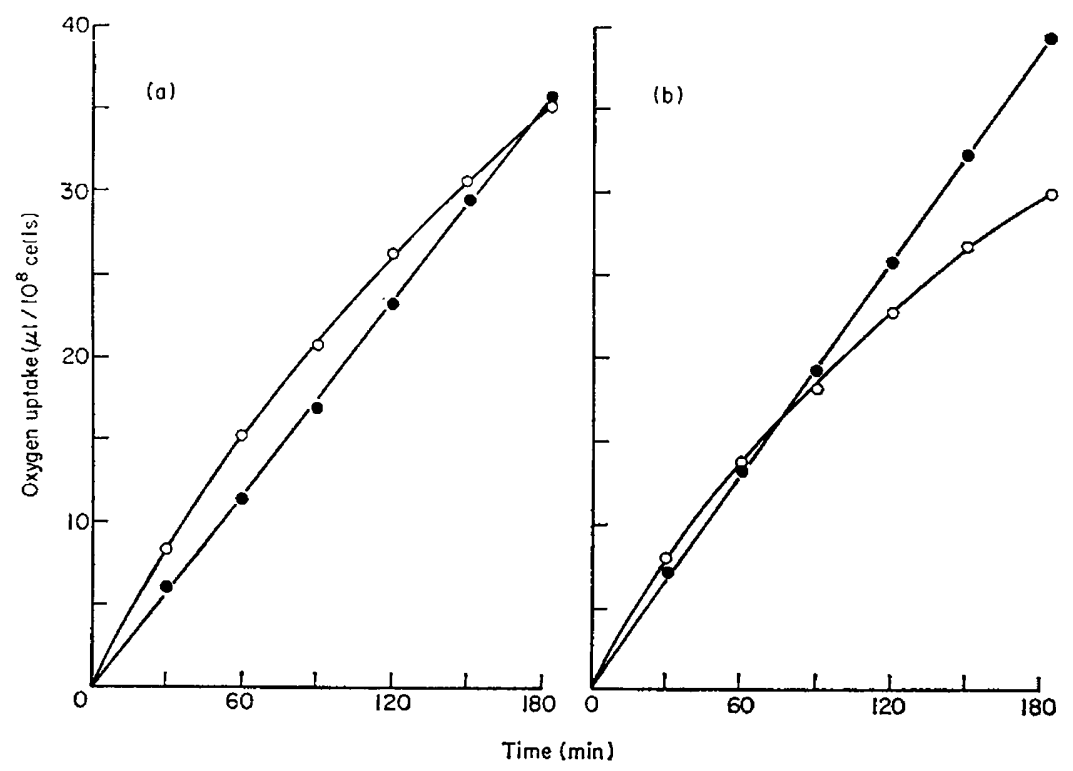

TexT-FIG. 1. Oxygen uptake of washed testicular (0) and ejaculated (0) spermatozoa from the same bulls incubated in (a) low phosphate and (b) high phosphate diluent. For further details of incubation, see text.

TABLE 2

SUMMARY OF THE ANALYSIS OF VARIANCE FOR THE FINAL OXYGEN UPTAKE IN TEXT-FIG. 1

\begin{tabular}{l|r|c}
\hline Source of variation & d.f. & Variance ratios \\
\cline { 2 - 3 } Spermatozoa & 1 & $19 \cdot 30^{* *}$ \\
Diluents & 1 & 0.07 \\
Interaction & 1 & $11.00^{* *}$ \\
Replicates & 10 & 3.04 \\
Residual & 30 & $13.50 \dagger$ \\
\hline \multirow{2}{*}{$P<0.01 ;$} & Tesidual mean square.
\end{tabular}

uptake of ejaculated cells was higher than that of testicular spermatozoa during the first $2 \mathrm{hr}$ of incubation but thereafter declined and by $3 \mathrm{hr}$ it was similar for both types of spermatozoa. In high phosphate buffer, the initial rate of respiration was similar for testicular and ejaculated spermatozoa but the 
oxygen uptake of the latter declined progressively with further incubation so that by $3 \mathrm{hr}$ there was a striking difference between the two cell types.

Glucose breakdown. Table 3 gives the results of experiments on the breakdown of [U- $\left.{ }^{14} \mathrm{C}\right]$ glucose by testicular and ejaculated spermatozoa. In a low phosphate diluent $(20 \mathrm{~mm})$, the uptake of glucose by testicular spermatozoa was less than that of ejaculated cells (84 versus $145 \mu \mathrm{g}$ ). However, high concentrations of phosphate stimulated glucose breakdown by testicular spermatozoa and depressed the activity of ejaculated cells so that in the presence of $80 \mathrm{~mm}$ phosphate, glucose was utilized at about the same rate by testicular and ejaculated cells (116 versus $117 \mu \mathrm{g}$ ).

TABLE 3

METABOLISM OF $\left[\mathrm{U}^{14}{ }^{14} \mathrm{C}\right] \mathrm{GLUGOSE}$ BY TESTIGULAR AND EJAGULATED BULL SPERMATOZOA

\begin{tabular}{c|c|c|c|c|c}
\hline Diluent & Spermatozoa & Glucose utilized & Glucose oxidized & $\begin{array}{c}{\left[{ }^{14} \text { C }\right] \text { lactic acid }} \\
\text { formed }\end{array}$ & $\begin{array}{c}\text { Total lactic acid } \\
\text { formed }\end{array}$ \\
\hline $\begin{array}{c}\text { Low phosphate } \\
(20 \mathrm{~mm})\end{array}$ & Testicular & $84 \cdot 0$ & $28 \cdot 0(33 \cdot 3)$ & $53 \cdot 0(63 \cdot 0)$ & $84 \cdot 2$ \\
High phosphate & Ejaculated & $145 \cdot 0$ & $29 \cdot 0(20 \cdot 0)$ & $102 \cdot 0(70 \cdot 3)$ & $106 \cdot 8$ \\
$(80 \mathrm{~mm})$ & Testicular & $116 \cdot 0$ & $29 \cdot 0(25 \cdot 0)$ & $80 \cdot 0(69 \cdot 0)$ & $115 \cdot 0$ \\
& Ejaculated & $117 \cdot 0$ & $27 \cdot 0(23 \cdot 1)$ & $81 \cdot 0(69 \cdot 2)$ & $86 \cdot 3$ \\
\hline
\end{tabular}

Values $\left(\mu \mathrm{g} / 10^{8}\right.$ cells) are the mean of two duplicate incubations from each of three bulls. The glucose utilized equals initial minus final amount; the glucose oxidized has been calculated from ${ }^{14} \mathrm{CO}_{2}$ collected in $\mathrm{KOH}(20 \% \mathrm{w} / \mathrm{v})$ in centre well; percentages are given in parentheses and relate to the glucose utilized.

TABLE 4

SUMMARY OF THE ANALYSES OF VARIANCE FOR THE DATA IN TABLE 3

\begin{tabular}{|c|c|c|c|c|c|}
\hline \multirow{3}{*}{ Source of variation } & \multirow{3}{*}{$d . f}$. & \multicolumn{4}{|c|}{ Variance ratios } \\
\hline & & \multirow{2}{*}{$\begin{array}{l}\text { Glucose } \\
\text { utilized }\end{array}$} & \multicolumn{2}{|c|}{ Glucose oxidized } & \multirow{2}{*}{ Lactic acid } \\
\hline & & & $(\%$ glucose uptake $) \dagger$ & $\left(\mu g / 10^{8}\right.$ cells $)$ & \\
\hline $\begin{array}{l}\text { Spermatozoa (A) } \\
\text { Diluents }(\mathrm{B}) \\
\text { Assay }(\mathrm{C}) \\
\text { Interactions } \\
\quad \mathrm{A} \times \mathrm{B} \\
\quad \mathrm{A} \times \mathrm{C} \\
\mathrm{B} \times \mathrm{C} \\
\text { Replicates } \\
\text { Residual }\end{array}$ & $\begin{array}{r}1 \\
1 \\
1 \\
1 \\
1 \\
1 \\
10 \\
30\end{array}$ & $\begin{array}{c}22 \cdot 10^{* *} \\
0 \cdot 12 \\
\\
21 \cdot 82^{* *} \\
\\
8 \cdot 50^{* *} \\
469 \cdot 0\end{array}$ & $\begin{array}{l}10 \cdot 10^{* *} \\
6 \cdot 00^{*} \\
15 \cdot 0\end{array}$ & $\begin{array}{l}0.00 \\
0.06 \\
\\
2.99\end{array}$ & $\begin{array}{c}3 \cdot 89 \\
0 \cdot 49 \\
11 \cdot 80^{* *} \\
\\
19 \cdot 74^{* *} \\
6 \cdot 34^{*} \\
995 \cdot 80^{* *} \\
10 \cdot 80^{* *} \\
684 \cdot 0 \ddagger\end{array}$ \\
\hline
\end{tabular}

* $P<0.05 ; \quad * * P<0.01 ; \dagger$ as angles (arcsin $\sqrt{ }$ percentage) corresponding to percentages; $¥ 71$ degrees of freedom.

In the low phosphate diluent, testicular spermatozoa also oxidized a higher proportion of the glucose to carbon dioxide than ejaculated cells (33.3 versus $20 \%$ ) with a correspondingly lower proportional accumulation of labelled lactic acid (63 versus $70 \cdot 3 \%$ ). In the high phosphate diluent, the proportions of glucose oxidized to carbon dioxide and the proportions accumulating as lactate were similar for both types of spermatozoa. 


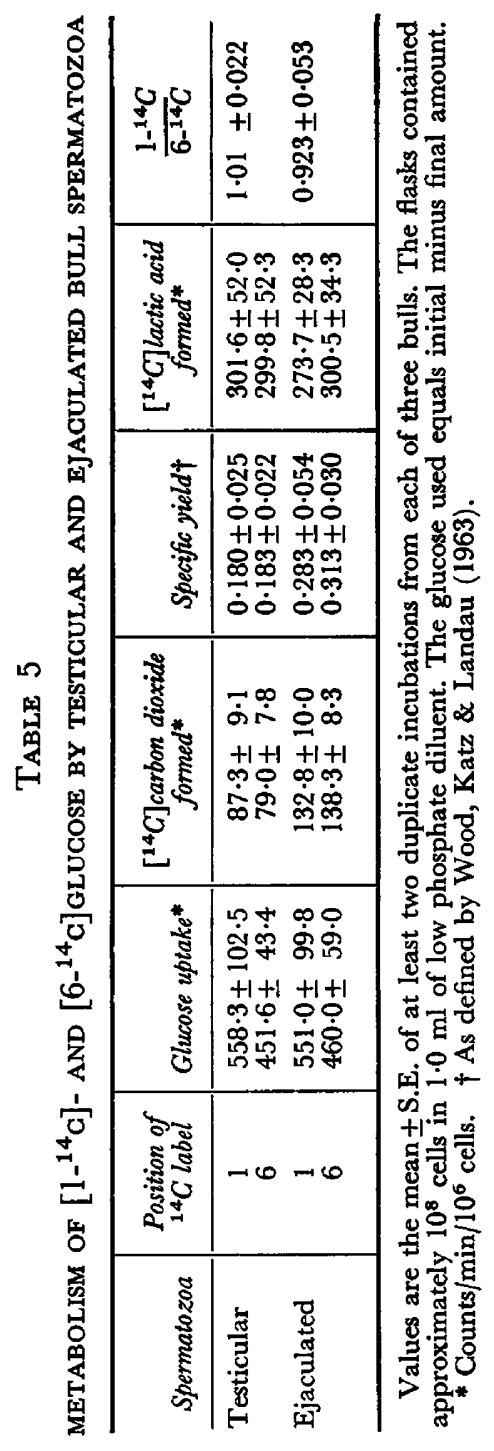


The radio-activity of the carbon dioxide and lactic acid accounted for more than $90 \%$ of the glucose utilized. No other metabolites were detectable with ejaculated spermatozoa but with testicular spermatozoa, about $2 \%$ (low phosphate diluent) and $5 \%$ (high phosphate diluent) of the utilized glucose appeared on the chromatogram with a mobility similar to certain amino acids (i.e. aspartic and glutamic acid; $R_{F}=0.08$ to 0.12 ) between the origin and the glucose $\left(R_{F}=0.58\right)$. Further, testicular spermatozoa produced more lactic acid than appeared as $\left[{ }^{14} \mathrm{C}\right]$ lactic acid on the chromatogram and only 64 to $70 \%$ of the total lactic acid present could have arisen from the radio-active glucose. Only traces of lactic acid were detectable in the washed sperm suspension before incubation.

Hexose monophosphate activity. Testicular and ejaculated spermatozoa were incubated in low phosphate diluent with glucose labelled specifically in the C-1 and C-6 positions. The ratios of the yields of ${ }^{14} \mathrm{CO}_{2}$ from $\left[1-{ }^{14} \mathrm{C}\right]$ glucose to that from $\left[6-{ }^{14} \mathrm{C}\right]$ glucose were 1.0 and 0.92 for testicular and ejaculated spermatozoa respectively and calculations of the specific yields of carbon dioxide, as defined by Wood, Katz \& Landau (1963), showed that glucose dissimilation through the pentose cycle (hexose monophosphate shunt activity) was negligible in both types of spermatozoa (Table 5).

This was further substantiated by the similarity of the amounts of radioactive lactic acid accumulated by both cell types from C-1 and C-6 glucose.

\section{DISCUSSION}

This successful technique for cannulating the testis of the living bull should greatly facilitate studies of testicular spermatozoa and the fluid in which they are transported into the head of the epididymis. Not only does it make abundant quantities of testicular secretion available for several days, but it also reduces the risk of contamination by other cells and body fluids and the dangers of post-mortem changes inherent in studies with slaughterhouse material.

A comparison of the volume (about $40 \mathrm{ml}$ ) of fluid secreted daily by the testis of a mature bull with that obtained from the cannulated epididymis (Bennett \& Rowson, 1963) substantiates the finding of Crabo (1965) that most of the fluid is resorbed by the epididymis. All the evidence suggests that this may take place in the first three segments of the bull's epididymis, resulting in a high concentration of spermatozoa (Nicander, 1958). The daily secretion of fluid and spermatozoa per $100 \mathrm{~g}$ of testis was about 62 and $75 \%$ respectively of that reported for Merino rams, although the total output per testis is of the same order in both species (Voglmayr et al., 1966; Voglmayr \& Mattner, 1968). The daily output of spermatozoa by each bull was comparable to the number of spermatozoa obtained by frequent ejaculation (Almquist, Hale \& Amann, 1958) but was only half the sperm production of dairy bulls as calculated from gonadal sperm reserves and quantitative testicular histology (Amann \& Almquist, 1962).

The composition of bull rete testis fluid was basically similar to that of the ram (see Setchell, Scott, Voglmayr \& Waites, 1969). However, the fluid 
collected from living bulls contained less potassium, calcium, lactic acid and protein but more urea and chloride than that obtained from animals at slaughter (Crabo, 1965; Wales et al., 1966). The different concentration of most constituents in rete testis fluid and blood plasma strongly suggests the existence of the same blood-rete testis fluid barrier recently reported for the ram (Setchell, Voglmayr \& Waites, 1969) and may have its site in the welldefined boundary tissue of the seminiferous tubules (Glermont, 1958; Lacy \& Rotblatt, 1960; Gardner \& Holyoke, 1964; Schmidt, 1964; Kagayama, Irisawa, Shirai \& Matsushita, 1965; Ross \& Long, 1966; Idänpään-Heikkilä, 1966; Ross, 1967). Certain characteristics of the fluid, particularly the high chloride concentration, indicate that rete testis fluid is a product of active secretion and not merely filtration.

Testosterone, when present, appeared in bull rete testis fluid at approximately the same concentration as in the fluid collected from living rams (Voglmayr et al., 1966; White \& Hudson, 1968) and the daily secretion, by way of the seminiferous tubules, from an average size testis was about $1 \%$ of the total testicular content (Lindner \& Mann, 1960). Thus, the developing germ cells and testicular spermatozoa are exposed to relatively high concentrations of testosterone which may play an important rôle in the maintenance of spermatogenesis (Walsh, Cuyler \& McCullagh, 1934). This high androgen environment extends into the head of the epididymis and may have important consequences for the survival of spermatozoa during their period of maturation (Moore, 1928; White \& Hudson, 1968).

Glutamic acid, the principal free amino acid in ram rete testis fluid (Setchell et al., 1967), was found in similar concentrations in the fluid collected from bulls. From these results, it can be calculated that secretion by the testis could account for most of the glutamic acid present in the bull ejaculate (Bhargava, Bishop \& Work, 1959). Setchell et al. (1967) have demonstrated that glutamic acid does not pass through the limiting tissue of the seminiferous tubules but is synthesized from glucose. Preliminary observations also suggest an inverse relation between the glutamic acid and glucose concentration in rete testis fluid and a direct correlation with sperm numbers (Voglmayr \& Setchell, unpublished observation). Thus, with decreasing sperm concentrations $\left(<20 \times 10^{6}\right.$ cells $\left./ \mathrm{ml}\right)$, less glutamic acid is detectable and at the same time significant amounts of glucose begin to appear in the fluid. At present, the significance of such high amino acid concentrations in rete testis fluid is difficult to assess; according to Setchell et al. (1967), they may create favourable conditions for nucleic acid synthesis within the seminiferous tubules since a number of amino acids have been shown to be involved in the synthesis of purine and pyrimidine bases (see Buchanan, 1960; Crosbie, 1960).

Testicular and ejaculated spermatozoa of the bull clearly differ in their response to the phosphate concentrations in the media. The present results confirm that high phosphate concentrations depress the respiration of ejaculated spermatozoa (see Salisbury \& Lodge, 1962) and also their glycolysis, under certain conditions of incubation (Wales \& Wallace, 1964). However, high phosphate concentrations stimulated the oxygen uptake of testicular spermatozoa and their utilization of glucose, which is in agreement with the 
results obtained for the ram (Voglmayr et al., 1967). In low phosphate diluent, testicular spermatozoa utilized less glucose than ejaculated cells and a greater percentage was converted to carbon dioxide. It seems likely that under these conditions, exogenous glucose can contribute a greater share of the carbon dioxide produced whereas, with high phosphate concentrations, more carbon dioxide is produced from concurrent endogenous metabolism. The rapid accumulation of lactic acid by bull testicular spermatozoa incubated in high phosphate diluent is in marked contrast to ram testicular spermatozoa which produce much less lactic acid from exogenous glucose under the same conditions (Voglmayr et al., 1967) but form considerable amounts of amino acids, mainly glutamic acid (Voglmayr et al., 1967). Since more lactic acid was formed by bull testicular spermatozoa than could have arisen from the glucose breakdown, there may be endogenous sources in the cell. The possibility that these may be reserve carbohydrates for hexoses such as glycogen or inositol (see Mann, 1964), which are broken down as spermatozoa pass through the epididymis, warrants further investigation.

The absence of an active pentose cycle in ejaculated bull spermatozoa confirms the work of Scott, White \& Annison (1962) but our results with testicular spermatozoa are in contrast to those of Wu, McKenzie, Fang \& Butts (1959) who found evidence of hexose monophosphate activity in spermatozoa collected from incisions into the testis parenchyma. Contamination of their preparations with testicular parenchyma may explain these conflicting results since this tissue has an active pentose cycle (Bloom, 1955; Field, Pastan, Herring \& Johnson, 1960; Setchell \& Hinks, 1967).

\section{ACKNOWLEDGMENTS}

The authors are indebted to Professor G. W. Emmens for his interest and advice. We are grateful to Dr R. F. Seamark for the hormone assays. This work has been aided by grants from the Ford Foundation and the Australian Meat Board.

\section{REFERENGES}

Almquist, J. O., Hale, E. B. \& Amann, R. P. (1958) Sperm production and fertility of dairy bulls at high-collection frequencies with varying degrees of sexual preparation. F. Dairy Sci. 41, 733.

Amann, R. P. \& Almovist, J. O. (1962) Reproductive capacity of dairy bulls. VIII. Direct and indirect measurement of testicular sperm production. 7. Dairy Sci. 45, 774.

Barker, J. N. \& Britton, H. G. (1957) The enzymatic estimation of $\mathrm{L}(+)$ lactic acid. F. Physiol., Lond. 138, 3P.

Bennetr, J. P. \& Rowson, L. E. A. (1963) A fistula for the collection of epididymal semen from the bull. F. Reprod. Fert. 6, 61.

Bhargava, P. M., Bishop, M. W. H. \& Work, T. S. (1959) Incorporation of $\left[{ }^{14} \mathrm{G}\right]$ amino acids into the proteins of bull spermatozoa. Biochem. 7. 73, 247.

Bishop, D. W. (1961) Biology of spermatozoa. In: Sex and Internal Secretions, 3rd edn, vol. 2, p. 707. Ed. W. C. Young. Williams \& Wilkins, Baltimore.

Bishop, M. W. H. \& Walton, A. (1960) Spermatogenesis and the structure of mammalian spermatozoa. In: Marshall's Physiology of Reproduction, 3rd edn, vol. 1, pt. 2, p. 94. Ed. A. S. Parkes. Longmans, Green, London.

Bцоoм, B. (1955) Catabolism of glucose by mammalian tissue. Proc. Soc. exp. Biol. Med. 88, 317.

Buchanan, J. M. (1960) Biosynthesis of purine nucleotides. In: The Nucleic Acids, p. 303. Eds. E. Chargaff and J. N. Davidson. Academic Press, New York. 
Burrer, D. R. (1962) A simple scintillation counting technique for assaying $\mathrm{C}^{14} \mathrm{O}_{2}$ in a Warburg flask. Analyt. Biochem. 4, 413.

BusH, I. E. (1952) Methods of paper chromatography of steroids applicable to the study of steroids in mammalian blood and tissues. Biochem. F. 50, 370.

CLermont, Y. (1958) Contractile elements in the limiting membrane of the seminiferous tubules of the rat. Expl Cell Res. 15, 438.

CraBo, B. (1965) Studies on the composition of epididymal content in bulls and boars. Acta vet. scand. 6, Suppl. 5.

Grabo, B. \& Gustafsson, B. (1964) Distribution of sodium and potassium and its relation to sperm concentration in the epididymal plasma of the bull. 7 . Reprod. Fert. 7, 337.

Crosbie, G. W. (1960) Biosynthesis of pyrimidine nucleotides. In: The Nucleic Acids, p. 323. Eds. E. Chargaff and J. N. Davidson. Academic Press, New York.

Field, J. B., Pastan, I., Herring, B. \& Johnson, P. (1960) Studies of pathways of glucose metabolism of endocrine tissues. Endocrinology, 67, 801 .

Fiske, G. H. \& Subbarow, Y. (1925) The colorimetric determination of phosphorus. F. biol. Chem. 66, 375.

Freinkel, N., Cohen, A. K., Arky, R. A. \& Foster, A. E. (1965) Alcohol hypoglycaemia. II. A postulated mechanism of action based on experiments with rat liver slices. F. clin. Endocr. Metab. $25,76$.

Gardner, P. J. \& Holyoke, E. A. (1964) Fine structure of the seminiferous tubule of the Swiss mouse. The limiting membrane, Sertoli cell, spermatogonia and spermatocytes. Anat. Rec. 150, 391.

Gustafsson, B. (1966) Luminal contents of the bovine epididymis under conditions of reduced spermatogenesis, luminal blockage and certain sperm abnormalities. Acta vet. scand., Suppl. 17.

Hancock, J. L. (1952) The morphology of bull spermatozoa. 7. exp. Biol. 29, 445.

Henle, G. \& Zrttle, C. A. (1942) Studies of the metabolism of bovine epididymal spermatozoa. Am. 7. Physiol. 136, 70 .

HugGerr, A. ST. G. \& Nixon, D. A. (1957) Use of glucose oxidase, peroxidase and o-dianisidine in determination of blood and urinary glucose. Lancet, $\mathbf{i i}, 368$.

IDÄNPÄÄN-HEIKKILÄ, P. (1966) Effect of local heat in vivo on the fine structure of the basement membrane and Sertoli cells of the rat testis. Fert. Steril. 17, 689.

Kagayama, M., Irisawa, S., Shirat, M. \& Matsushita, S. (1965) Contractile cells in the boundary tissue of the seminiferous tubules. Fap. 7. Urol. 56, 842.

LACY, D. \& RotblatT, J. (1960) Study of the normal and irradiated boundary tissue of the seminiferous tubules of the rat. Expl Cell Res. 21, 49.

Lardy, H. A., Hansen, R. G. \& Phillips, P. H. (1945) The metabolism of bovine epididymal spermatozoa. Archs Biochem. 6, 41.

LindNer, H. R. \& MANN, T. (1960) Relationship between the content of androgenic steroids in the testes and the secretory activity of the seminal vesicles in the bull. F. Endocr. 21, 341.

Lowry, O. H., Rosebrough, A., FARr, A. L. \& RANDall, R. J. (1951) Protein measurement with Folin phenol. 7. biol. Chem. 193, 265.

Mans, T. (1964) The biochemistry of semen and of the male reproductive tract. Methuen, London.

Martin, I. G. A. \& Rees, D. (1962) The use of direct current pulses for the electro-ejaculation of the bull. Aust, vet. F. 38, 92 .

MOORE, C. R. (1928) On the properties of the gonads as controllers of somatic and physical characteristics. X. Spermatozoan activity and the testis hormone. J. exp. Zool. 50, 455.

Murdoch, R. N. \& WhrTe, I. G. (1968) Metabolic studies of testicular, epididymal, and ejaculated spermatozoa of the ram. Aust. 7. biol. Sci. 21, 111.

Nicander, L. (1958) Studies on the regional histology and cytochemistry of the ductus epididymis in stallions, rams and bulls. Acta morph. neerl.-scand. 1, 337.

ORGEBIN-CRIsT, M. G. (1961) Recherches expérimentales sur la durée de passage des spermatozoides dans l'épididyme du taureau. Thesis, Université de Lyon.

Redenz, E. (1925) Der Nebenhoden als morphologisches Problem. II. Die Bedeutung der Elektrolytresorption für die Beweglichkeit der Spermien. Verh. anat. Ges., Jena, 34, 180.

Redenz, E. (1933) Über den Spaltungsstoffwechsel der Säugetierspermatozoa im Zusammenhang mit der Beweglichkeit. Biochem. Z. 257, 234.

Ross, M. H. (1967) The fine structure and development of the peritubular contractile cell component in the seminiferous tubules of the mouse. Am. F. Anat. 121, 523.

Ross, M. H. \& Long, I. R. (1966) Contractile cells in human seminiferous tubules. Science, N.Y. 153, 1271.

Salisbury, G. W. \& Cragle, G. (1956) Freezing point depression and mineral levels of fluids of the ruminant male reproductive tract. Proc. 3rd Int. Congr. Anim. Reprod., Cambridge, 1, 25.

Salisbury, G. W. \& Lodge, J. R. (1962) Metabolism of spermatozoa. Adv. Enzymol. 24, 35. 
Scнмгт, F. G. (1964) Licht und elektronenmikroskopische Untersuchungen am menschlichen Hoden und Nebenhoden. Z. Zellforsch. mikrosk. Anat. 63, 707.

Scott, T. W., Voglmayr, J. K. \& Setcheld, B. P. (1967) Lipid composition and metabolism in testicular and ejaculated ram spermatozoa. Biochem. $\mathcal{7 . ~ 1 0 2 , ~} 456$.

Scott, T. W., White, I. G. \& Annison, E. F. (1962) Glucose and acetate metabolism by ram, bull, dog and fowl spermatozoa. Biochem. 7. 83, 398.

Setchell, B. P. \& Hinks, N. T. (1967) The importance of glucose in the oxidative metabolism of the testis of the conscious ram and the role of the pentose cycle. Biochem. F. 102, 623 .

Setchell, B. P., Hinks, N. T., Voglmayr, J. K. \& Scott, T. W. (1967) Amino acids in ram testicular fluid and semen and their metabolism by spermatozoa. Biochem. F. 105, 1061 .

Setchele, B. P., Scott, T. W., Voglmayr, J. K. \& Wattes, G. M. H. (1969) Characteristics of testicular spermatozoa and the fluid which transports them into the epididymis. Biol. Reprod. $1,40$.

Setchell, B. P., Voglmayr, J. K. \& Waites, G. M. H. (1969) A blood-testis barrier restricting passage from blood into rete testis fluid but not into lymph. 7. Physiol., Lond. 200, 73.

SOWERBY, J. M. \& Ottaway, J. H. (1966) The enzymatic estimation of glutamate and glutamine. Biochem. 7. 99, 246.

Umbreit, W. W., Burris, R. H. \& Stauffer, J. F. (1959) Manometric techniques in tissue metabolism. Burgess, Minneapolis.

Voglmayr, J. K. \& Mattner, P. E. (1968) Compensatory hypertrophy in the remaining testis following unilateral orchidectomy in the adult ram. F. Reprod. Fert. 17, 179.

Voglmayr, J. K., Scott, T. W., Setchell, B. P. \& Wartes, G. M. H. (1967) Metabolism of testicular spermatozoa and characteristics of testicular fluid collected from conscious rams. $\mathcal{H}$. Reprod. Fert. 14, 87.

Voglmayr, J. K., Wattes, G. M. H. \& Setchell, B. P. (1966) Studies on spermatozoa and fluid collected directly from the testis of the conscious ram. Nature, Lond. 210, 861.

Wales, R. G. \& Walrace, J. C. (1964) Effects of diluent composition on the metabolism of bull, dog, rabbit and fowl spermatozoa. 7. Reprod. Fert. 8, 361.

Wales, R. G., Wallace, J. C. \& White, I. G. (1966) Composition of bull epididymal and testicular fluid. F. Reprod. Fert. 12, 139.

WAzsh, E. L., GuYler, W. K. \& MCCullaGH, D. R. (1934) The physical maintenance of the male sex gland. Am. F. Physiol. 107, 508.

White, I. G. \& Hudson, B. (1968) The testosterone and dehydroepiandrosterone concentration in fluids of the mammalian male reproductive tract. F. Endocr. 41, 291.

WriLrs, J. B. (1965) The analysis of biological materials by atomic-absorption spectroscopy. Clin. Chem. 11, 251.

Wrison, B. W. (1966) Automatic estimation of urea using urease and alkaline phenol. Clin. Chem. 12, 360 .

Wood, H. G., KATZ, J. \& LANDAU, B. R. (1963) Estimation of pathways of carbohydrate metabolism. Biochem. Z. 338, 809.

Wu, S. H., MaKenzie, F. F., Fang, S. C. \& Butts, J. S. (1959) Pathways of glucose utilization in epididymal and testicular sperm cells. F. Dairy Sci. 42, 110.

ZALL, D. M., Fisher, D. \& Garner, M. Q. (1956) Photometric determination of chlorides in water. Analyt. Chem. 28, 1665. 